Martin D. Henry (ITQ, vol. 70/3, 2005, 262)

\title{
Catholicism and Protestantism
}

At its inception in the early sixteenth century, Protestantism saw itself as a purified, 'reformed' expression of the Christian faith. In the eyes of the Protestant Reformers, Christianity had become corrupt in the hands of the Catholic Church and needed to be restored to the alleged purity of its pristine beginnings.

Whatever about the accuracy of the Reformers' perception of early sixteenth-century Catholic Christianity, and whatever about the reservations one might have concerning the Reformed Churches' ability to deliver on their promise of a restored, purified Christianity, the Reformation does at least seem to have highlighted a fundamental, and perhaps irreconcilable split in the way Christianity can be construed.

Putting the matter in a rather painful nutshell, what the Reformation, more than earlier reform movements within Western Christianity, appears to have succeeded in clarifying is that Catholicism is primarily a religion of 'externals', Protestantism a religion of 'internals'. Catholicism, with its stress on material creation, the external world, the sacraments (sacraments being traditionally regarded as 'visible signs of invisible grace'), the body (whether glorified in baroque art or castigated for 'sins of the flesh'), or on physically attending Mass on Sundays, is inextricably wedded to a vision of Christianity as a visible, tangible, palpable, in a word 'external' reality. Protestantism, on the other hand, with its stress on the individual's inner conviction, on his or her personal relationship with God, on the illumination of the Christian man or woman by the Holy Spirit, is inextricably wedded to a vision of Christianity as an essentially invisible, intangible, and, as far as human observation goes, imperceptible, in a word 'internal' reality. 
In extreme cases, Catholicism can appear hypocritical to the point of being the very antithesis of Christianity, as the startling lines from a play by the Spanish dramatist Luis Vélez de Guevara (1579-1644) insinuate: 'I can well be a bad Christian but a good Catholic' (quoted by Gerald Brenan in The Literature of the Spanish People (Harmondsworth: Penguin Books, 1963), p. 412). Protestantism, on the other hand, by playing off, 'in Luther's words, "the wisdom of our flesh" and "the wisdom of the word of God", (Walter Kaufmann), can create a strained, bogus spirituality, repudiated by Protestantism's most uncompromising critic, Friedrich Nietzsche, in the trenchant aphorism: 'Pure spirit is pure lie' (The Antichrist, §8, tr. R. J. Hollingdale).

Could it be, then, that the Reformation was not at bottom about God at all - 'How can I find a gracious God?' (Luther's anguished question) - but about human beings, and the status of their material or bodily being? In yearning to abolish life's ambiguity, Protestantism was no doubt seeking to realize Christianity's most seductive promise. In resisting the temptation to be 'pure', Catholicism left itself open, as it must always do, to the charge of hypocrisy. But the silver lining of this particular cloud is that, by accepting that the body is a mask, not a mirror, of the soul ('persona' originally means 'mask'), Catholicism acknowledges human beings to be God's permanently ambiguous creatures, and God, the Creator and Redeemer, to be the only authentic interpreter of humanity's masks. 